\title{
JURMAT PAJALANDONBSTE
}

(Indonesian Tax Journal)

www.jurnal.stan.ac.id/index.php/JPI

\section{WITHHOLDING TAX ATAS BUNGA DALAM \\ TRANSAKSI FINANCIAL TECHNOLOGY LENDING}

\author{
Sulfan \\ Politeknik Keuangan Negara STAN
}

Alamat Korespondensi: sulfan76@pkn.stan.ac.id

\section{INFORMASI ARTIKEL}

Diterima Pertama

[27 09 2019]

Dinyatakan Diterima

[02 01 2020]

KATA KUNCI:

Withholding Tax, Fintech Lending

KLASIFIKASI JEL:

H2O

\begin{abstract}
Fintech Lending in Indonesia is developing very rapidly which is marked by the accumulation of loans up to June 2019 reaching Rp44.8 trillion. Borrowers are generally individuals and Micro, Small and Medium Enterprises (MSMEs) with a total of 9.7 million borrowers. There are indications of problems with taxation of interest income in the withholding tax mechanism. The purpose of this study is to get an idea of the extent of the Fintech Lending business process so that it is known to the parties who are obliged to withhold Article 23/26 Income Tax on interest income in the withholding tax mechanism. This study concludes that there are difficulties in applying the mechanism of withholding tax through withholding income tax Article $23 / 26$ so that it can be proposed to be subject to final taxation of interest income in Fintech Lending transactions.
\end{abstract}

\section{ABSTRAK}

Fintech Lending di Indonesia berkembang sangat pesat yang ditandai akumulasi pinjaman sampai dengan Juni 2019 mencapai Rp44,8 triliun. Umumnya peminjam adalah perorangan dan Usaha Mikro, Kecil, dan Menengah (UMKM) dengan total 9,7 juta peminjam. Terdapat indikasi permasalahan pengenaan pajak atas penghasilan bunga dalam mekanisme withholding tax. Tujuan penelitian ini untuk mendapat gambaran sejauhmana proses bisnis Fintech Lending sehingga diketahui pihak-pihak yang berkewajiban sebagai pemotong PPh Pasal 23/26 atas penghasilan bunga dalam mekanisme withholding tax. Penelitian ini menyimpulkan bahwa terdapat kesulitan penerapan mekanisme withholding tax melalui pemotongan PPh Pasal 23/26, sehingga dapat diusulkan untuk dikenakan pemajakan yang bersifat final atas penghasilan bunga dalam transaksi Fintech Lending. 


\section{PENDAHULUAN}

Industri layanan jasa pinjam meminjam berbasis teknologi informasi atau dikenal Financial Technology Peer to Peer Lending (Fintech Lending) berkembang cukup pesat di Indonesia. Per Juni 2019, penyelenggara/platform Fintech Lending yang terdaftar atau berizin di Otoritas Jasa Keungan (OJK) sebanyak 113 perusahaan, akumulasi penyaluran pinjaman Rp44,8 triliun atau tumbuh $97,68 \%$ dengan rata-rata pinjaman yang disalurkan Rp3,76 miliar per bulan, jumlah akumulasi rekening lender 498 ribu, jumlah akumulasi rekening borrower 9,7 juta, jumlah akumulasi transaksi lender 23,9 juta, dan jumlah akumulasi transaksi borrower 33,1 juta. Bahkan diperkirakan akumulasi penyaluran pinjaman melalui Fintech Lending dengan menggunakan compounded annual growth rate (CAGR) di akhir tahun 2020 sebesar Rp223 triliun, atau naik kurang lebih Rp200 triliun dibandingkan akhir tahun 2018 (PwC, Juni 2019).

Gambar 1: Perkembangan Fintech Lending di Indonesia

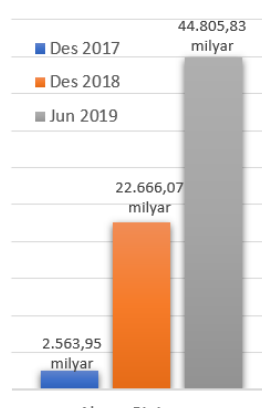

Akum. Pinjaman

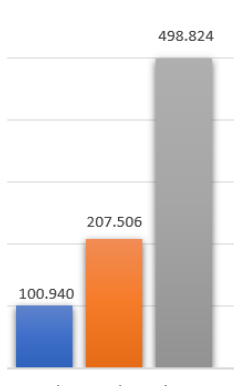

Akum. Rek Lender

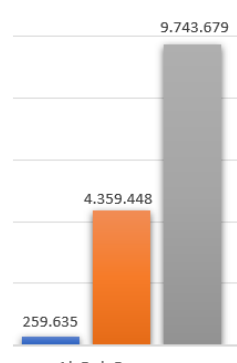

Ak Rek Borrower
Sumber: Otoritas Jasa Keuangan (Juni, 2019)

Tumbuh kembangnya Fintech Lending tidak lepas dari keterbatasan akses masyarakat, baik perorangan maupun Usaha Mikro, Kecil, dan Menengah (UMKM), meminjam dari perbankan. Di tahun 2018, terdapat kurang lebih 186 juta perorangan untuk segmen menengah dan bawah pengeluaran per kapita yang sebagian besar sekitar $71 \%$ atau 127,8 juta perorangan tidak mendapat akses kredit. Sedangkan UMKM yang tidak mempunyai akses pinjaman sebanyak 46 juta atau 74\% dari total 63 juta UMKM (PwC Indonesia, Juni 2019). Padahal perorangan dan UMKM diharapkan sebagai penopang mesin pertumbuhan ekonomi Indonesia.

Fintech Lending semakin disukai dan menjadi alternatif pinjaman bagi masyarakat dengan beberapa alasan. Pertama, Fintech Lending menjangkau masyarakat yang tidak memiliki riwayat pinjaman atau kesulitan meminjam ke bank. Kedua, pinjaman Fintech Lending dapat dengan mudah diakses 24 jam sehari melalui perangkat apapun. Ketiga, pencairan pinjaman lebih cepat, lebih akuntabel, dan lebih efisien. Dan terakhir, bagi UMKM, pinjaman Fintech Lending menawarkan bunga binjaman yang jauh lebih kompetitif dibandingkan dengan yang ditawarkan pasar keuangan informas, misal rentenir (LPEM FEB UI, 2019).

Dari sisi investor, munculnya Fintech Lending juga menjadi alternatif pilihan investasi yang menarik selain jenis-jenis investasi yang sudah mapan atau berkembang sebelumnya, seperti deposito, surat hutang, unit link, reksadana dan saham. Pertama, tingkat suku bunga Fintech Lending yang kompetitif. Suku bunga untuk tujuan konsumtif dibatasi OJK maksimal 0,8\% per hari atau setara dengan tingkat pengembalian tahunan sebesar $16,61 \%$. Sedangkan, suku bunga untuk tujuan produktif berkisar 14\%-20\% per tahun. Suku bunga ini sebanding bahkan lebih kompetitif dibandingkan dengan tingkat suku bunga skema pinjaman informal lainnya (LPEM FEB UI, 2019). Dan kedua, keberhasilan platform Fintech Lending menekan angka nonperforming loan (NPL) yang ditunjukkan tingginya tingkat keberhasilan platform Fintech Lending dalam memfasilitasi penyelesaian kewajiban borrower kepada lender dalam jangka waktu 90 hari, yakni sebesar 98,25\% (OJK, Jun 2019).

Hasil penelitian INDEF selama kurun waktu 20172018, berkembangnya Fintech Lending memberikan dampak positif terhadap perekonomian Indonesia, yakni telah menambah Produk Domestik Bruto (PDB) sebesar Rp25,97 triliun. Secara sektoral, Fintech Lending mampu menstimulus pertumbuhan sektor jasa keuangan, asuransi, jasa perusahaan, dana pensiun, dan informasi komunikasi. Penyerapan tenaga kerja sebanyak 215.433 orang dan menambah pendapatan tenaga kerja dalam bentuk upah dan gaji sebesar Rp4,56 triliun. Temuan lain, Fintech Lending terbukti meningkatkan perekonomian melalui penyaluran kredit, khususnya sektor UMKM (INDEF, 2018).

Berkaitan dengan pajak, tentunya penghasilan berupa imbal hasil modal (passive income) berupa bunga yang diterima pihak yang memberikan pinjaman/lender merupakan objek Pajak Penghasilan (PPh), hal ini merujuk Undang-Undang Nomor 7 Tahun 1983 s.t.t.d. Undang-Undang Nomor 36 Tahun 2008 tentang Pajak Penghasilan (UU PPh). Namun, masih menjadi bahan perdebatan bagaimana seharusnya pengenaan withholding PPh atas bunga pinjaman Fintech Lending ini.

\section{LANDASAN TEORI}

\subsection{Withholding Tax menurut Para Ahli}

Withholding tax adalah pembayaran pajak dilakukan melalui pemungutan atau pemotongan atas obyek yang terutang pajak, yang dilakukan oleh pihak lain (pihak ketiga) yang diberi kewenangan untuk menghitung dan memotong atau memungut pajak orang lain dan menyetorkannya ke kas negara ${ }^{1}$.

\footnotetext{
${ }^{1}$ A. Anshari Ritonga, Pengantar Ilmu Hukum Pajak \& Perpajakan Indonesia (Pustaka El Manar, 2017)
} 
R. Mansyuri (1992) mengutip Thomas G. Vitez mengenai kelebihan dan kekurangan withholding tax, menyebutkan bahwa kelebihan withholding tax system $^{2}$, yaitu: 1) dapat digunakan untuk meningkatkan kepatuhan sukarela, karena penerima pembayaran/ penghasilan wajib melaporkan penghasilan yang telah dipotong pajaknya, jika tidak akan teridentifikasi dari laporan pemotong pajak; 2) pajak terutang otomatis terkumpul dari penerima pembayaran yang tidak melaporkan penghasilannya dan tidak menyampaikan Surat Pemberitahuan (SPT); 3) metode untuk mempromosikan keadilan pajak, pajak yang terutang telah dibayar oleh penerima pembayaran, baik dilaporkan atau tidak dilaporkan pajaknya; 4) menggurangi masalah pemungutan pajak bagi otoritas pajak; dan, 5) merupakan cara yang nyawan bagi Wajib Pajak untuk membayar pajaknya. Sedangkan kekurangan withholding tax system ${ }^{3}$ adalah: 1) dapat menciptakan kesulitan bagi Wajib Pajak tertentu karena kemungkinan timbulnya efek kelebihan pemotongan pajak; dan, 2) menimbulkan biaya tambahan bagi pemotong pajak yang melakukan administrasi pemotongan pajak.

Withholding tax menghasilkan penerimaan pajak secara otomatis dalam jumlah besar dan tidak memerlukan upaya yang besar ${ }^{4}$. Secara tradisional di banyak negara, withholding tax dirancang untuk penghasilan yang bersifat pasif, terutama hanya untuk penghasilan berupa bunga, gaji, dan dividen ${ }^{5}$. Aaron (1996) juga menyebutkan bahwa pemerintah di banyak negara umumnya mengenakan withholding tax atas transaksi antar negera seperti pembayaran bunga, royalti, dan pembayaran dividen ${ }^{6}$. Pajak-pajak atas penghasilan tersebut secara formal merupakan kewajiban para penerima pembayaran untuk melaporkan. Tetapi pihak yang melakukan pemotongan pajak atas bunga, royalti, atau dividen adalah pihak yang melakukan pembayaran penghasilan ${ }^{7}$. Dengan kata lain, pemotong pajak adalah pemberi penghasilan.

Bagaimana withholding tax diterapkan terhadap penghasilan yang bersifat aktif (business income). Yudkin menyatakan tidaklah mudah menetapkan tarif untuk withholding system bagi business income ${ }^{8}$. Kesulitan itu muncul karena besarnya pajak yang terutang bergantung kepada hasil keseluruhan operasi tahun bersangkutan, apabila subjek pajak mengalami kerugian, maka tarif withholding tax sekecil apapun akan menyebabkan

\footnotetext{
2 R. Mansury, The Indonesian Income Tax: A Case Study In Tax Reform, (Rotterdam: Erasmus Universiteit, 1992)

${ }^{3}$ ibid

${ }^{4}$ Leon Yudkin, A Legal Structure For Effective Income Tax Administration, (Cambridge: Heffeman Press Inc., 1971)

${ }^{5}$ Victor Thuronyi, ed., Tax Law Design and Drafting Vol. 2, (Washington D.C.: International Monetary Fund, 1998)

${ }^{6}$ Henry J. Aaron, Economic Effects of Fundamental Tax Reform, (Washington D. C.: Brookings Institution Press) ${ }^{7}$ ibid
}

lebih bayar pajak di akhir tahun ${ }^{9}$. Griffith menyatakan bahwa pemotongan pajak dapat dilakukan atas pembayaran gaji dan pembayaran lainnya atas penghasilan modal, tetapi tidak mungkin dapat merancang sistem withholding tax yang memuaskan atas penghasilan dari perkebunan, penghasilan usaha, dan penghasilan investasi, serta jasa professional ${ }^{10}$.

Menurut Thuronyi, withholding system domestik dapat diterapkan terhadap individu yang berwiraswasta, namun secara administratif tidaklah mungkin menerapkan withhholding tax pada semua pembayaran yang diterima oleh individu tersebut ${ }^{11}$. Thuronyi menyatakan bahwa withholding tax pada individu wiraswasta lebih tepat bagi bisnis dengan jumlah pelanggan yang relatif kecil yang diikuti oleh adanya batas pengenaan (threshold) sebelum withholding tax diterapkan ${ }^{12}$. Thuronyi juga menambahkan, jika tarif withholding tax yang berdasarkan penghasilan kotor dikenakan terlalu tinggi, maka withholding tax akan menyebabkan lebih bayar pajak dalam tahun pajak yang bersangkutan serta akan menyebabkan masalah cash-flow yang serius bagi pembayar pajak ${ }^{13}$.

\subsection{Withholding Tax atas Bunga menurut Undang-Undang Perpajakan Indonesia}

Bagaimana pengaturan withholding tax di Indonesia? Ketentuan atau pengaturan withholding tax terdapat di Pasal 4 ayat (2), 21, 22, 23, dan 26 UU PPh. Ketentuan yang diatur dalam pasal tersebut umumnya merupakan pembayaran pajak dalam tahun berjalan melalui pemotongan pajak yang dapat diperhitungkan atau menjadi kredit pajak untuk penghitungan pajak yang akan disetor dalam suatu tahun pajak, kecuali pemotongan atau pemungutan yang bersifat final.

Kaitan dengan penghasilan berupa imbal hasil modal (passive income) berupa bunga yang diterima pihak yang memberikan pinjaman/lender, di bawah ini diuraikan secara singkat pengaturan pengenaan withholding tax dalam UU PPh.

Penghasilan berupa bunga yang dikenakan PPh Pasal 23 sebesar $15 \%$ adalah penghasilan bunga selain yang telah dikenakan PPh Pasal 4 ayat (2) atau PPh Final. Terdapat beberapa penghasilan bunga yang dikenakan PPh Final, yakni:

a. Bunga deposito dan tabungan serta diskonto Sertifikat Bank Indonesia, termasuk bunga yang diterima atau diperoleh dari deposito dan tabungan

\footnotetext{
${ }^{8}$ Leon Yudkin, A Legal Structure For Effective Income Tax Administration, (Cambridge: Heffeman Press Inc., 1971) ${ }^{9}$ ibid

${ }^{10}$ Patrick L. Kelley dan Oliver Oldman, ed, Readings On Income Tax Administration, (New York: Harvard Law School, 1973)

11 Victor Thuronyi, ed., Tax Law Design and Drafting Vol. 2, (Washington D.C.: International Monetary Fund, 1998)

12 ibid

13 ibid
} 
yang ditempatkan di luar negeri melalui bank yang didirikan atau bertempat kedudukan di Indonesia atau cabang bank luar negeri di Indonesia. Pengecualian pemotongan PPh final atas bunga deposito dan tabungan serta diskonto Sertifikat Bank Indonesia, apabila diterima atau diperoleh bank dan dana pensiun, jumlahnya tidak melebihi Rp7.500.000,00 dan bukan merupakan jumlah yang dipecah-pecah, dan bunga tabungan pada bank yang ditunjuk pemerintah dalam rangka pemilikan rumah dengan klasifikasi tertentu ${ }^{14}$.

b. Bunga obligasi, termasuk diskonto, atas obligasi yang dapat berupa surat utang, surat utang negara, dan obligasi daerah, yang berjangka waktu lebih dari 12 (dua belas) bulan. Pemotongan PPh final atas bunga obligasi tidak berlaku apabila penerima penghasilannya berupa Wajib Pajak Dana Pensiun yang telah ditetapkan oleh Menteri Keuangan dan Wajib Pajak bank yang didirikan di Indonesia atau cabang bank luar negeri di Indonesia ${ }^{15}$. Untuk penghasilan berupa bunga obligasi yang diterima oleh Wajib Pajak bank dikenai PPh berdasarkan tarif umum sesuai UU PPh.

c. bunga simpanan yang dibayarkan oleh koperasi yang didirikan di Indonesia kepada anggota koperasi orang pribadi ${ }^{16}$

Pemotong PPh Pasal 23 menurut UU PPh yakni badan pemerintah, subjek pajak badan dalam negeri, penyelenggaran kegiatan, Bentuk Usaha Tetap (BUT) atau perwakilan perusahaan luar negeri, dan Orang pribadi sebagai wajib pajak dalam negeri yang ditunjuk oleh Direktur Jenderal Pajak, yaitu akuntan, arsitek, dokter, notaris, PPAT (kecuali Camat), pengacara, konsultan, yang melakukan pekerjaan bebas; dan, Orang pribadi yang menjalankan usaha yang menyelenggarakan pembukuan atas pembayaran berupa sewa ${ }^{17}$.

Dalam hal penghasilan berupa bunga termasuk premium, diskonto, dan imbalan sehubungan dengan jaminan pengembalian utang diterima oleh Wajib Pajak luar negeri, dilakukan pemotongan PPh Pasal 26 sebesar $20 \%$ atau berdasarkan Persetujuan Penghindaran Pajak Berganda (P3B) oleh badan pemerintah, subjek pajak dalam negeri, penyelenggaran kegiatan, BUT, atau perwakilan perusahaan luar negeri lainnya.

Pemotongan PPh Pasal 23/26 dilakukan oleh Pemotong pada saat terutangnya PPh Pasal 23/26, yakni pada saat pembayaran, atau saat disediakan untuk dibayarkan (seperti: dividen) dan jatuh tempo (seperti: bunga dan sewa), atau saat yang ditentukan dalam kontrak atau perjanjian atau faktur (seperti: royalti, imbalan jasa teknik atau jasa manajemen atau jasa

\footnotetext{
14 Peraturan Pemerintah Nomor 131 Tahun 20.00 s.t.t.d. Peraturan Pemerintah 123 Tahun 2015

15 Peraturan Pemerintah Nomor 100 Tahun 2013 s.t.t.d. Peraturan Pemerintah Nomor 55 Tahun 2019.

16 Peraturan Pemerintah Nomor 15 Tahun 2009

${ }^{17}$ Keputusan Direktur Jenderal Pajak Nomor KEP-50/PJ./1996
}

lainnya), tergantung peristiwa mana yang lebih dulu terjadi. Pengertian saat disediakan untuk dibayarkan, dibagi menjadi dua, yakni: pertama, untuk perusahaan yang tidak go public, adalah saat dibukukan sebagai utang dividen yang akan dibayarkan, yaitu pada saat pembagian dividen diumumkan atau ditentukan dalam Rapat Umum Pemegang Saham (RUPS) Tahunan. Demikian pula apabila perusahaan yang bersangkutan dalam tahun berjalan membagikan dividen sementara (dividen interim), maka PPh Pasal 23/26 terutang pada saat diumumkan atau ditentukan dalam Rapat Direksi atau pemegang saham sesuai dengan Anggaran Dasar perseroan yang bersangkutan. Kedua, untuk perusahaan yang go public, adalah pada tanggal penentuan kepemilikan pemegang saham yang berhak atas dividen (recording date). Dengan perkataan lain pemotongan PPh 23/26 atas dividen baru dapat dilakukan setelah para pemegang saham yang berhak menerima atau memperoleh dividen tersebut diketahui, meskipun dividen tersebut belum diterima secara tunai. Sedangkan, yang dimaksud dengan saat jatuh tempo pembayaran adalah saat kewajiban untuk melakukan pembayaran yang didasarkan atas kesepakatan, baik yang tertulis maupun tidak tertulis dalam kontrak atau perjanjian atau faktur ${ }^{18}$.

\section{METODE PENELITIAN}

Penelitian ini menggunakan metode pendekatan kualitatif. Tehnik pengumpulan data dilakukan melalui sumber pustaka, buku, jurnal, data-data yang dipublikasikan, dan internet, yang relevan dengan tujuan penulisan. Inventarisasi informasi dan/atau keterangan dilakukan untuk mengetahui sejauhmana perkembangan Fintech Lending, model proses bisnis secara umumu dan yang berlaku saat ini di Indonesia, sertapermasalahan terutama kaitannya dengan withholding tax.

\section{HASIL PENELITIAN}

\subsection{Proses Bisnis Fintech Lending}

Jenis kegiatan bisnis Fintech Lending bervariasi sangat signifikan antar negara maupun di dalam suatu negara karena sangat heterogennya model bisnis penyelenggara/platform Fintech Lending ${ }^{19}$. Terdapat lima model proses bisnis Fintech Lending yang diidentifikasi oleh Financial Stability Board $(\mathrm{FSB})^{20}$, antara lain:

a. Model Tradisional

Plarform Fintech Lending berfungsi menyediakan pasar online atau marketplace, tempat bertemunya

\footnotetext{
18 Peraturan Pemerintah Nomor 94 Tahun 2010 s.t.t.d. Peraturan Pemerintah Nomor 45 Tahun 2019

${ }^{19}$ Fintech Credit, market structure, business models and financial stability implications. Financial Stability Board. Committee on Global Financial System. Mei 2017

20 ibid
} 
penerbit. Bank menerima pembayaran sejumlah pinjaman yang dijanjikan dalam promissory note ${ }^{21}$.

Platform juga mengunggah permintaan pinjaman dari borrower di laman plarform untuk ditawarkan ke calon lender untuk mendanai pinjaman. Apabila dana dari para lender mencukupi untuk mendanai borrower, platform segera membeli promissory note dari bank penerbit. Platform menerbitkan pass through certificates (PTC) kepada para lenders sesuai proporsi dana dalam pinjaman tunggal. Platform membebankan biaya administrasi ke para lender. Saat pelunasan pinjaman, borrower melunasi pinjaman ke platform untuk kemudian diteruskan ke para lender ${ }^{22}$.

yang diperoleh, dan tingkat risiko kredit atau indicato kualitas kredit. Calon kreditor atau lender memilih untuk mendanai calon borrower yang telah tersedia di platform. Kontrak pinjam meminjam terjadi antara calon borrower dan calon lender, bukan dengan platform. Penyaluran dana dan pembayaran pinjaman (pokok dan bunga) melalui akun bank tersendiri (misal, virtual account) yang terpisah dari akun bank milik platform. Platform memperoleh pendapatannya dari fee yang dikenakan dari pihak-pihak yang bertransaksi, baik dari borrower, lender, atau keduanya.

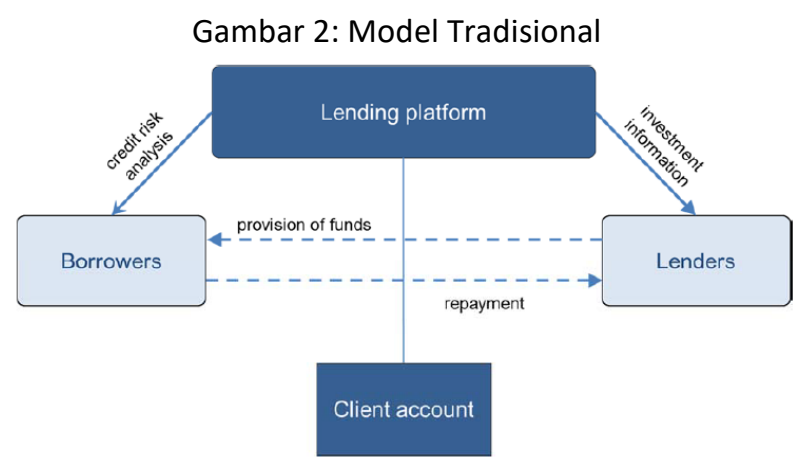

Sumber: Fintech Credit, market structure, business models and financial stability implications. Financial Stability Board. Committee on Global Financial System. Mei 2017

\section{b. Model Notaris}

Proses bisnis Fintech Lending dalam model notaris melibatkan bank komersial sebagai mitra borrower dan lender. Bank berfungsi sebagai penyedia dana agar pinjaman segera sampai ke borrower. Proses model notaris dimulai calon borrower mengirimkan permintaan pinjaman ke platform. Platform Fintech Lending meneruskan permintaan pinjaman ke bank komersial yang terasosiasi dengan platform, bank kemudian menyetujui pinjaman dan menerbitkan surat promes/sanggup bayar (promissory note) kepada platform. Platform meneruskan ke borrower dan membebaninya dengan fee administrasi. Borrower kemudian menyerahkan promissory note ke bank

\footnotetext{
${ }^{21} \mathrm{http} / / /$ vinodkothari.com/2015/11/peer-to-peer-lendingbusiness-models/ 22 ibid
}

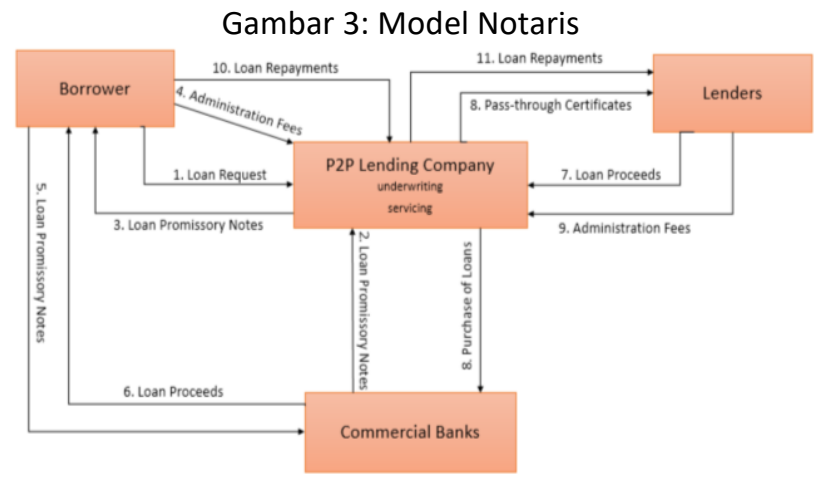

Sumber: http://vinodkothari.com/2015/11/peer-topeer-lending-business-models/

\section{c. Model Pengembalian yang Dijamin}

Proses bisnis model pengembalian yang dijamin hampir sama dengan model tradisional. Berbeda halnya dengan platform pada model tradisional yang tidak menjamin pengembalian pokok dan bunga pinjaman dari borrower ke lender, platform pada model pengembalian yang dijamin memberikan garansi atau jaminan pengembalian pokok dan bunga kepada lender.

\section{Gambar 4: Model Pengembalian yang Dijamin}

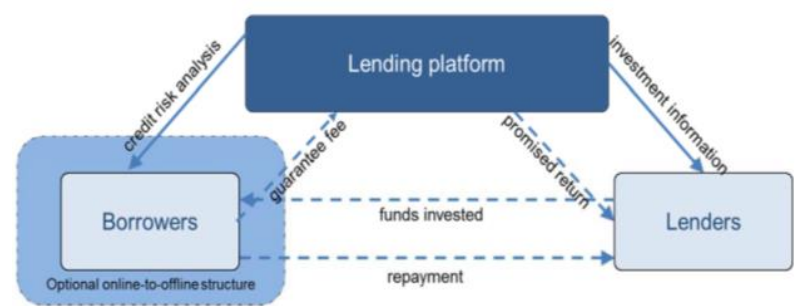

Sumber: Fintech Credit, market structure, business models and financial stability implications. Financial Stability Board. Committee on Global Financial System. Mei 2017

\section{d. Model Neraca}

Proses bisnis platform pada Fintech Lending model neraca hampir mirip dengan model bisnis Lembaga pembiayaan nonbank ${ }^{23}$. Platform

\footnotetext{
${ }^{23}$ Fintech Credit, market structure, business models and financial stability implications. Financial Stability Board. Committee on Global Financial System. Mei 2017
} 
mendapatkan dana dari investor untuk kemudian mendanai pinjaman borrower.

Perbedaan utama model bisnis ini dengan model Fintech Lending model tradisional adalah saat terjadi pinjaman macet. Dalam Fintech Lending model tradisional, platform tidak memberikan pinjaman kepada peminjam tetapi hanya menghubungkan borrower dengan lender untuk membuat perjanjian pinjam-meminjam. Sehingga lender bertanggung jawab sendiri terhadap risiko apabila borrower gagal bayar. Platform pada model neraca menanggung risiko sendiri atas pinjaman yang diberikan ke borrower sehingga secara langsung bertanggungjawab atas segala kerugian apabila borrower gagal bayar ${ }^{24}$.

\section{Gambar 5: Model Neraca}

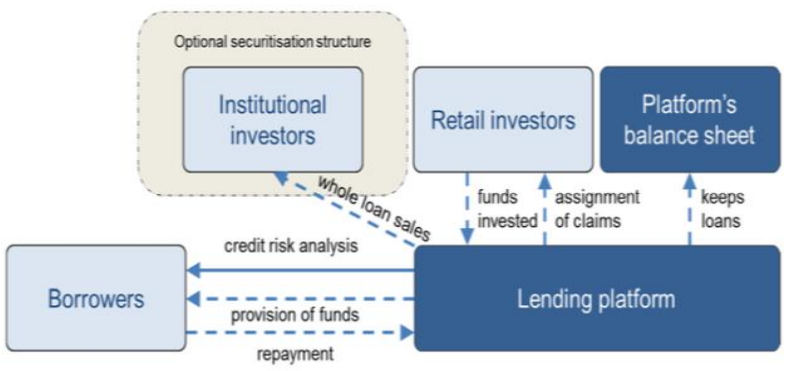

Sumber: Fintech Credit, market structure, business models and financial stability implications. Financial Stability Board. Committee on Global Financial System. Mei 2017

\section{e. Model Invoice Trading}

Model proses bisnis invoice trading merupakan bentuk pembiayaan invoice yang masih belum dibayar dan ditawarkan oleh calon borrower untuk dijual kepada investor atau lender melalui platform Fintech Lending. Dalam model ini, pelaku bisnis (borrower) mendaftarkan satu atau beberapa invoice yang belum terbayar di platform. Harga setiap invoice ditetapkan secara otomatis oleh platform berdasarkan perjanjian dimuka dengan harga antara 70\%-90\%, termasuk tingkat diskonto atau bunga yang akan diterima oleh lender. Borrower membayar biaya atau fee kepada platform. Lender investor yang menggunakan platform untuk membiayai invoice borrower, juga membayar fee kepada platform. Lender menerima pengembalian pembiayaan dan bunga yang telah disepakati dari borrower ${ }^{25}$.

Bagaimana model proses bisnis Fintech Lending di Indonesia. Pengaturan model bisnis Fintech Lending di Indonesia secara tegas telah diatur dalam Peraturan Otoritas Jasa Keuangan Nomor 77/POJK.01/2016 tentang Layanan Pinjam Meminjam Uang Berbasis Teknologi. Penyelenggara atau platform merupakan badan hukum yang menyediakan, mengelola, dan

\footnotetext{
${ }^{24}$ https://p2pmarketdata.com/balance-sheet-lending/

25 https://invoiceinterchange.com.au/what-is-invoicetrading/

26 Peraturan Otoritas Jasa Keuangan Nomor 77/POJK.01/2016
}

mengoperasikan layanan pinjam meminjam berbasis teknologi informasi. Platform hanya berfungsi mempertemukan borrower dengan lender dalam rangka perjanjian pinjam meminjam ${ }^{26}$. Platform diwajibkan menggunakan escrow account dan virtual account. Pemberian pinjaman dari lender melalui escrow account untuk kemudian diteruskan ke virtual account borrower. Sama halnya dengan pemberian pinjaman, pelunasan berupa pokok dan bunga pinjaman borrower melalui escrow account untuk kemudian diteruskan ke virtual account lender. Tujuan kewajiban penggunaan virtual account dan escrow account dalam penyelenggaraan kegiatan layanan pinjam meminjam uang berbasis teknologi informasi, yaitu larangan bagi penyelenggara dalam melakukan penghimpunan dana masyarakat melalui rekening penyelenggara ${ }^{27}$.

Selain hal tersebut, OJK melarang platform diantaranya melakukan kegiatan usaha selain usaha sebagai platform, bertindak sebagai pemberi dan penerima pinjaman. Memberikan jaminan dalam segala bentuknya atas pemenuhan kewajiban pihak lain, menerbitkan surat hutang. Berdasarkan pengaturan dan pembatasan proses bisnis atau kegiatan usaha platform Fintech Lending oleh OJK, model proses bisnis Fintech Lending di Indonesia merupakan model bisnis tradisional dimana fungsi platform Fintech Lending hanya sebagai penyedia market online sebagai tempat bertemuanya calon borrower dengan calon lender.

\subsection{Withholding Tax Bunga atas Transaksi Fintech Lending}

Potensi pajak atas penghasilan bunga dari transaksi pinjam-meminjam melalui platform Fintech Lending sangat besar. Perhitungan penghasilan bunga yang diterima lender dari pinjaman yang disalurkan ke borrower untuk kurun waktu 2017 s.d. Juni 2019 sebesar Rp7,44 triliun.

Tabel 1: Perhitungan Bunga yang Diterima Lender dari Transaksi Fintech Lending

\begin{tabular}{|l|r|r|}
\hline Tahun & $\begin{array}{c}\text { Nilai Pinjaman } \\
\text { (jutaan Rp) }\end{array}$ & $\begin{array}{c}\text { Perkiraan Rata- } \\
\text { Rata Penghasilan } \\
\text { Bunga setahun*) } \\
\text { (jutaan Rp) }\end{array}$ \\
\hline 2017 & $2.563 .950,00$ & $425.872,10$ \\
\hline 2018 & $20.102 .119,50$ & $3.338 .962,05$ \\
\hline 2019 (sd Jun) & $22.139 .764,43$ & $3.677 .414,87$ \\
\hline Total & $44.805 .833,93$ & $7.442 .249,02$ \\
\hline
\end{tabular}

Sumber: Data OJK (diolah)

*) menggunakan asumsi bunga harian $0,8 \%$ atau bunga tahunan $16,61 \%$

\footnotetext{
27 Penjelasan pasal 24 Peraturan Otoritas Jasa Keuangan Nomor 77/POJK.01/2016
} 
Bunga pinjaman yang diperoleh lender dalam transaksi pinjam-meminjam melalui melalui platform Fintech Lending merupakan penghasilan pasif, seperti halnya penghasilan bunga yang diterima investor yang berinvestasi di pasar obligasi, surat utang, tabungan/deposito, maupun penghasilan berupa capital gain yang diperoleh di pasar keuangan lainnya. Pemajakan atas penghasilan bunga umumnya melalui mekanisme withholding tax, baik pengenaan secara final maupun tidak final. Pertimbangan pengenaan melalui mekanisme ini, utamanya adalah menghasilkan penerimaan pajak yang cepat dan besar. Disamping pertimbangan lainnya, antara lain: mendorong investasi, kesederhanaan pemungutan pajak, mengurangi beban administrasi bagi Wajib Pajak dan dan otoritas pajak, pemerataan keadilan pajak, dan memerhatikan perkembangan ekonomi dan moneter ${ }^{28}$.

Sejatinya kewajiban pajak atas penghasilan bunga merupakan kewajiban penerima bunga, dalam transaksi pinjam-meminjam Fintech Lending berarti berada di pihak investor atau lender. Dalam mekanisme withholding tax, pemotongan pajaknya menjadi kewajiban di pihak yang melakukan pembayaran bunga, yakni penerima pinjaman atau borrower.

Apakah platform Fintech Lending bisa sebagai pihak yang berkewajiban melakukan pemotongan pajak? Perlu dilihat proses bisnis yang bagaimana platform Fintech Lending memberikan penghasilan bunga kepada lender. Dari gambaran beberapa proses bisnis Fintech Lending di pembahasan sebelumnya, platform Fintech Lending pada model tradisional, model notaris, dan model invoice trading, hanya berfungsi sebagai perantara antara borrower dan lender dengan menyediakan jasa layanan pasar online atau marketplace. Platform menerima penghasilan berupa fee atas penggunaan jasa tersebut yang dibayar oleh borrower atau lender, atau bahkan oleh keduanya. Platform Fintech Lending dalam proses bisnis ini tidak melakukan pembayaran bunga kepada pihak lender. Sehingga tidak berkewajiban melakukan pemotongan pajak. Untuk model notaris, saat promissory note yang diterbitkan bank tidak dapat dibeli oleh platform karena tidak ada lender yang membeli, borrower berkewajiban melakukan pembayaran pokok pinjaman dan bunga kepada bank sebagai penerbit promissory note. Kewajiban pemotongan pajak atas penghasilan bunga yang diterima oleh bank menjadi kewajiban borrower. Namun demikian, ketentuan aturan perpajakan di Indonesia menyatakan bahwa penghasilan yang dibayar atau terutang kepada bank termasuk yang dikecualikan dari pemotongan pajak $^{29}$, sehingga tidak ada mekanisme pemotongan pajak atas penghasilan bunga dari borrower ke bank.

Platform Fintech Lending yang menggunakan model pengembalian yang dijamin, dapat bertindak sebagai pihak yang membayar bunga ke lender pada

28 Penjelasan pasal 4 ayat (2) Undang-Undang Nomor 7 Tahun 1983 s.t.t.d. Undang-Undang Nomor 36 Tahun 2008 saat borrower tidak dapat mengembalikan pokok pinjaman dan bunga ke lender. Platform dalam model bisnis ini telah menjamin pengembalian pinjaman dari lender ke borrower. Sedangkan dalam model bisnis neraca, platform bertindak seperti layaknya lembaga keuangan yang mencari investor atau lender untuk menanamkan modalnya di platform untuk kemudian disalurkan sebagai pinjaman oleh platform itu sendiri ke borrower. Kewajiban pemotongan pajak dalam model bisnis pengembalian yang dijamin saat borrower tidak sanggup membayar dan pada model neraca berada di pihak platform yang membayar penghasilan bunga.

Model bisnis Fintech Lending di Indonesia yang terdaftar dan berizin dari OJK menggunakan model bisnis tradisional/invoice trading. Hal ini ditegaskan dalam peraturan OJK Nomor 77/POJK.01/2016 yang mengatur bahwa fungsi platform hanya sebatas mempertemukan borrower dan lender. Peraturan OJK melarang platform melakukan kegiatan seperti halnya lembaga keuangan yang menghimpun dan kemudian menyalurkannya dalam bentuk pinjaman, juga melarang platform memberikan jaminan pengembalian pengembalian pokok pinjaman dan bunga ke lender atas pemberian pinjamannya ke borrower.

Pihak yang berkewajiban melakukan pemotongan pajak dalam mekanisme withholding tax atas penghasilan bunga dalam transaksi Fintech Lending di Indonesia, adalah pihak yang membayarkan bunga yakni pihak borrower. Pihak platform belum memungkinkan sebagai pihak pemotong pajak atas penghasilan bunga yang diterima lender, karena bukan pihak yang membayarkan penghasilan bunga tersebut. Hal ini, tegas diatur dalam Pasal 23 UU PPh yang mengatur pihak yang membayarlah yang ditunjuk sebagai pemotong PPh atas penghasilan berupa bunga.

Namun demikian, umumnya borrower dalam proses bisnis Fintech Lending di Indonesia merupakan perorangan baik sebagai pendanaan konsumsi maupun pendanaan untuk kegiatan UMKM. Akibatnya muncul pertanyaan pihak siapa yang berkewajiban yang melakukan pemotongan PPh atas penghasilan berupa bunga tersebut. Perorangan tidak dapat ditunjuk sebagai pihak yang memotang pajak. Pasal 23 ayat (1) UU PPh menyebutkan bahwa atas penghasilan dengan nama dan dalam bentuk apapun yang dibayarkan, disediakan untuk dibayarkan, atau telah jatuh tempo pembayarannya oleh badan pemerintah, subjek pajak badan dalam negeri, penyelenggara kegiatan, bentuk usaha tetap, atau perwakilan perusahaan luar negeri lainnya kepada Wajib Pajak dalam negeri atau bentuk usaha tetap dipotong pajak oleh pihak yang wajib membayarkan, antara lain sebesar $15 \%$ dari jumlah bruto atas bunga. Perorangan bisa ditunjuk sebagai pemotong PPh, namun hanya dibatasi untuk Pengacara, Akuntan, Arsitek, Dokter, Konsultan, Notaris, Penilai, dan Aktuaris, yang melakukan pekerjaan bebas, dan

29 Pasal 23 ayat (4) huruf a Undang-Undang Nomor 7 Tahun 1983 s.t.t.d. Undang-Undang Nomor 36 Tahun 2008 
orang pribadi yang menjalankan usaha yang menyelenggarakan pembukuan ${ }^{30}$.

Berbeda halnya dengan pengaturan pada Pasal 23 UU PPh yang terbatas menunjuk subjek pajak orang pribadi sebagai pemotong pajak, Pasal 26 UU PPh mengatur semua subjek pajak dalam negeri (termasuk subjek pajak orang pribadi) sebagai pemotong PPh Pasal 26 atas penghasilan yang dibayarkan kepada Wajib Pajak Luar Negeri selain bentuk usaha tetap. Namun demikian, dimungkinkan dapat terjadi kesulitan pengawasan pemotongan PPh Pasal 26 apabila borrower membayarkan bunga kepada lender luar negeri yang disebabkan borrower tidak mengetahui siapa dan berasal darimana lender yang memberikan pinjaman.

Dilihat dari sisi compliance cost Wajib Pajak, biaya administrasi pemotong pajak sangat tinggi karena setiap melakukan pembayaran bunga wajib menerbitkan bukti pemotongan. Asumsi tiap borrower melakukan angsuran pokok pinjaman dan bunga sebanyak tiga kali, maka selama periode 2017 s.d. Juni 2019 diperoleh angka sekitar 29 juta kali pembayaran bunga. Sama halnya dengan pemerintah yang dalam hal ini Direktorat Jenderal Pajak (DJP), besarnya cost of collection yang harus mengadministrasikan bukti pemotongan tersebut.

Keterbatasan pengaturan PPh Pasal 23 yang tidak menunjuk perorangan sebagai pemotong pajak juga bisa terjadi kesulitan pemotongan PPh Pasal 26 dalam hal borrower perorangan membayar penghasilan bunga ke lender yang berasal dari asing. Untuk mengatasi sulitnya pengenaan pajak ini dapat diatasi dengan penerbitan ketentuan pemotongan pajak yang bersifat final dengan peraturan pemerintah sesuai Pasal 4 ayat (2) UU PPh. Ketentuan pajak yang bersifat final bisa merujuk ketentuan pemotongan PPh atas transaksi di bursa saham, dimana pihak pemotong adalah bursa atau bisa juga disebut platform yang mempertemukan penjual dan pembeli dalam transaksi jual-beli saham. Tarif PPh Final yang bisa diterapkan misalnya dengan tarif efektif 2,5\% atas jumlah pinjaman yang disalurkan dari lender ke borrower. Pihak yang ditunjuk pemotong pajak adalah platform Fintech Lending dengan pertimbangan sistem informasi transaksi penyaluran dan pembayaran pinjaman telah terintegrasi dengan platform.

\section{SIMPULAN}

Pinjam meminjam online melalui penyelenggara/platform Fintech Lending sangat dimintai masyarakat. Data statistik Fintech Lending per Juni 2019 yang dikeluarkan OJK menunjukkan penyaluran akumulasi pinjaman sasmpai dengan Juni 2019 sebesar Rp44,8 triliun. Besarnya penyaluran pinjaman melalui Fintech Lending dipicu keterbatasan akses masyarakat terutama perorangan dan UMKM meminjam ke lembaga keuangan formal, misalnya bank. Faktor lainnya adalah mudahnya akses 24 jam ke platform Fintech Lending, pencairan yang cepat, lebih akuntabel, lebih efisien, dan menawarkan bunga pinjaman yang kompetitif.

Pengenaan pemotongan PPh atas penghasilan bunga dalam transaksi pinjam meminjam Fintech Lending perlu mempertimbangkan model proses bisnisnya. Terdapat lima jenis model proses bisnis platform Fintech Lending. Fungsi platform pada model tradisional, model notaris, dan model invoice trading hanya berfungsi sebagai penyedia pasar online atau marketplace bagi calon borrower dan lender. Platform untuk model proses bisnis tersebut hanya mendapatkan fee dari borrower dan/atau lender. Pihak yang berkewajiban melakukan pemotongan PPh adalah pihak pemberi penghasilan bunga yakni borrower. Untuk model notaris, dalam pengaturan UU PPh dapat dimungkinkan tidak ada objek pemotongan PPh ketika promissory note tidak terjual ke lender. Untuk model pengembalian yang terjamin, platform dapat bertindak sebagai pihak yang memberikan penghasilan bunga ke lender ketika borrower tidak dapat melunasi kewajibannya. Sedangkan pada model neraca, platform bertindak sepenuhnya sebagai pihak yang memberikan penghasilan ke lender karena fungsi platform sepenuhnya sebagai lembaga pembiayaan. Pengaturan model proses bisnis Fintech Lending di Indonesia sesuai peraturan OJK Nomor 77/POJK.01/2016 adalah model tradisional/invoice trading yang mengatur platform hanya bertindak sebagai sarana bertemunya borrower dan lender.

Terdapat kesulitan penerapan withholding tax PPh Pasal 23/26 atas penghasilan bunga dalam transaksi pinjam meminjam Fintech Lending di Indonesia. Pihak borrower umumnya perorangan/UMKM yang berdasarkan ketentuan bukan pihak pemotong PPh 23 yang ditunjuk undang-undang untuk melakukan pemotongan atas bunga yang dibayarkan atau terutang ke lender. Disamping itu, kesulitan pengawasan pemotongan PPh Pasal 26 apabila asal pinjaman berasal dari lender asing. Mengatasi hal tersebut dapat mengatur ketentuan pajak yang spesifik dengan ketentuan pemajakan yang bersifat final seperti halnya pemotongan PPh Final atas transaksi di bursa saham.

\section{DAFTAR PUSTAKA}

Aaron, Henry J. dan William G. Gale (1996) Economic Effects of Fundamental Tax Reform. Washington D. C.: Brookings Institution Press.

Adhinegara, Bhima Yudhistira et.al (2018). Peran Fintech Lending Dalam Ekonomi Indonesia. INDEF Monthly Brief Vol.2/Issue 2/Agustus 2018. Jakarta.

${ }^{30}$ Keputusan Direktur Jenderal Pajak Nomor KEP-50/PJ./1994 
Direktorat Jenderal Pajak (1996). Keputusan Direktur Jenderal Pajak Nomor KEP-50/PJ./1996 tentang Penunjukan Wajib Pajak Orang Pribadi Dalam Negeri Tertentu sebagai Pemotong Pajak Penghasilan atas Penghasilan dari Persewaan Tanah dan/atau Bangunan

Financial Stability Board (2017). Fintech Credit, market structure, business models and financial stability implications. Committee on Global Financial System.

Invoice Interchange (2019). What is Invoice Trading? Website: https://invoiceinterchange.com.au/whatis-invoice-trading/

Kelley, Patrick L. dan Oliver Oldman (1973). Readings On Income Tax Administration. New York: Harvard Law School.

LPBEM FEB Universitas Indonesia (2019). Macroeconomic Analysis Series: Indonesia Economic Outlook, Q2-2019. website: https://www.lpem.org/ macroeconomic-analysis-series-indonesiaeconomic-outlook-q2-2019/

Otoritas Jasa Keuangan (2016). Peraturan Otoritas Jasa Keuangan Nomor 77/POJK.01/2016 tentang Layanan Pinjam Meminjam Uang Berbasis Teknologi Informasi

Otoritas Jasa Keuangan (2019). Statistik Fintech Lending Periode Juni 2019. Website: https://www.ojk.go.id/id/kanal/iknb/data-danstatistik/fintech/Default.aspx

P2Pmarketdata (2019). Balance Sheet Lending: What is it and how does it differ from P2P Lending? Website: https://p2pmarketdata.com/balance-sheetlending/

Pemerintah Republik Indonesia (2009). Peraturan Pemerintah Nomor 15 Tahun 2009 tentang Pajak Penghasilan Atas Bunga Simpanan yang Dibayarkan oleh Koperasi Kepada Anggota Koperasi Orang Pribadi

Pemerintah Republik Indonesia (2019). Peraturan Pemerintah Nomor 100 Tahun 2013 s.t.t.d. Peraturan Pemerintah Nomor 55 Tahun 2019 tentang Pajak Penghasilan atas Penghasilan berupa bunga obligasi. Jakarta: Pemerintah Republik Indonesia

Pemerintah Republik Indonesia (2019). Peraturan Pemerintah Nomor 94 Tahun 2010 s.t.t.d. Peraturan Pemerintah Nomor 45 Tahun 2019 tentang Penghitungan Penghasilan Kena Pajak dan Pelunasan Pajak Penghasilan dalam Tahun Berjalan

Price waterhouse Coopers (2019). Indonesia's Fintech Lending: Driving Economic Growth Through Financial Inclusion-Jun 2019. PwC Indonesia-Fintech Series.

R. Mansury (1992), The Indonesia Income Tax, A Case Study in Tax Reform, Rotterdam, Erasmus Universiteit.
Republik Indonesia (2008). Undang-Undang Nomor 7 Tahun 1983 sttd Undang-Undang No 36 Tahun 2008 tentang Pajak Penghasilan. Jakarta Republik Indonesia

Ritonga, A. Anshari (2017). Pengantar Ilmu Hukum Pajak \& Perpajakan Indonesia. Jakarta: Pustaka El Manar

Roy, Ameet (2015). Peer to Peer Lending: Business Models.

Website:

http://vinodkothari.com/2015/11 /peer-to-peerlending-business-models/

Thuronyi, Victor (1998). Tax Law Design and Drafting Vol. 2. Washington D.C.: International Monetary Fund.

Yudkin, Leon (1971). A Legal Structure For Effective Income Tax Administration. Cambridge: Heffeman Press Inc. 